\title{
Blood and feather concentrations of toxic elements in a Baltic and an Arctic seabird population
}

\section{Fenstad, Anette A.}

2017-01-30

Fenstad, A A , Bustnes , J O , Lierhagen , S , Gabrielsen , K M , Öst , M , Jaatinen , K , Hanssen , S A , Moe , B , Jenssen , B M \& Krokje , A 2017 , ' Blood and feather concentrations of toxic elements in a Baltic and an Arctic seabird population ', Marine Pollution Bulletin , vol. 114 , no. 2 , pp. 1152-1158 . https://doi.org/10.1016/j.marpolbul.2016.10.034

http://hdl.handle.net/10138/309482

https://doi.org/10.1016/j.marpolbul.2016.10.034

cc_by_nc_nd

acceptedVersion

Downloaded from Helda, University of Helsinki institutional repository.

This is an electronic reprint of the original article.

This reprint may differ from the original in pagination and typographic detail.

Please cite the original version. 
Blood and Feather Concentrations of Toxic Elements in a Baltic and an Arctic Seabird Population

Anette A. Fenstad ${ }^{a^{*}}$, Jan O. Bustnes ${ }^{b}$, Syverin Lierhagen ${ }^{c}$, Kristin M. Gabrielsen $^{a}$, Markus Öst ${ }^{\mathrm{d}, \mathrm{e}}$, Kim Jaatinen ${ }^{\mathrm{e}}$, Sveinn A. Hanssen ${ }^{\mathrm{b}}$, Børge Moe $^{\mathrm{f}}$, Bjørn M. Jenssen ${ }^{\mathrm{a}}$ and Åse Krøkje $\mathrm{a}^{\mathrm{a}^{*}}$

a Norwegian University of Science and Technology (NTNU), Department of Biology, Realfagbygget, 7491 Trondheim, Norway

b Norwegian Institute for Nature Research (NINA), Framsenteret, Hjalmar Johansens gate 14, 9296 Tromsø, Norway

c NTNU, Department of Chemistry, Realfagbygget, 7491 Trondheim, Norway

d Environmental and Marine Biology, Faculty of Science and Engineering, Åbo Akademy University, Artillerigatan 6, FI-20520 Turku, Finland

e Novia University of Applied Sciences (NOVIA), Coastal Zone Research Team, Raseborgsvägen 9, Fl-10600 Ekenäs, Finland

f NINA, Høgskoleringen 9, 7034 Trondheim, Norway

${ }^{*}$ corresponding authors 


\section{ABSTRACT}

We report blood and feather concentrations of elements in the Baltic Sea and Arctic population of common eiders (Somateria mollissima). The endangered Baltic Sea population of eiders was demonstrably affected by element pollution in the 1990s. While blood concentrations of Hg were higher in Baltic breeding eiders, blood Se, As and Cd concentrations were higher in Arctic eiders. Blood concentrations of $\mathrm{Pb}, \mathrm{Cr}, \mathrm{Zn}$ and $\mathrm{Cu}$ did not differ between the two populations. While blood $\mathrm{Pb}$ concentrations had declined in Baltic eiders since the 1990s, Hg concentrations had not declined, and were above concentrations associated with adverse oxidative effects in other bird species. Inconsistent with blood concentrations, feather concentrations suggested that $\mathrm{Pb}, \mathrm{Zn}$, and $\mathrm{Cd}$ exposure was higher in Baltic eiders, and that $\mathrm{Hg}$ exposure was higher in Arctic eiders. Our study thus emphasizes the need for comprehensive evaluation of toxic element status, covering the annual cycle of a species.

Key words: Common eiders, heavy metals, pollution, environmental exposure 
Toxic elements are considered a major pollution problem because of their negative effects on humans and wildlife, including damage to liver and bones, birth defects, cancer, alteration of genetic and enzyme systems, and damage to nervous and immune systems (Koivula and Eeva, 2010; Nordberg et al., 2014). Although these elements occur naturally in the environment, human activities such as metal smelting, combustion, ore processing, battery manufacturing and recycling cause significant additional anthropogenic releases of elements. All organisms have to cope with element stress, either from exposure to non-essential toxic elements or from depletion, or excess of essential elements. The metals mercury $(\mathrm{Hg})$, cadmium $(\mathrm{Cd})$ and lead $(\mathrm{Pb})$, as well as the metalloid arsenic (As) are toxic and non-essential, while the metals chromium $(\mathrm{Cr})$, copper $(\mathrm{Cu})$, and zinc $(\mathrm{Zn})$, as well as the non-metal selenium (Se) are essential but become toxic at levels above background (Nordberg et al., 2014). Sediments are the ultimate sink for aquatically emitted elements, and coastal environments may have elevated levels of contaminants due to run off, point source pollution, river influxes, atmospheric transport and deposition (Nordberg et al., 2014). Sea ducks are large-bodied marine birds which primarily feed on benthic invertebrates. These species, notably the common eider (Somateria mollissima, hereafter eider), are therefore recognized as important indicators of ecological health and inshore marine pollution (Savinov et al., 2003; Goodale et al., 2008; Meattey et al., 2014). Their exposure to some elements may, therefore, be relatively high compared to other marine birds that are pelagic feeders (Henny et al., 1995). Furthermore, eiders are long-lived birds that may accumulate certain elements, and be chronically exposed to elevated levels of these elements (Wayland et al., 2001). The eider is therefore a good study species for contaminant monitoring in coastal 
and inshore marine habitats (Franson et al., 2004; Mallory et al., 2004; Mallory et al., 2014; Provencher et al., 2014).

In the majority of avian studies, toxic element concentrations have been determined in tissue such as liver or kidney (Garcá-Fernández et al., 1996; Eisler, 2010; Shore et al., 2011; Binkowski and Meissner, 2013), a method that requires that the birds are killed. However, many marine bird species are considered threatened (Croxall et al., 2012), and non-destructive techniques using feather, blood and addled eggs are therefore preferable due to animal welfare concerns (Eisler, 2010). Furthermore, non-destructive sampling techniques make it possible to study survival rates in relation to contaminant exposure. Consequently, non-lethal sampling methods are increasingly being used to report toxic element concentrations (Wayland et al., 2007; Burger and Gochfeld, 2009). Blood element concentration is indicative of recent dietary exposure (Evers et al., 2008; Wayland and Scheuhammer, 2011), while feather element concentration indicates blood and body concentrations at the time of moulting (Markowski et al., 2013). The aim of the present study was to document blood and feather concentrations of toxic elements in the Baltic Sea and Svalbard eider population. The Baltic Sea has been considered one of the most polluted seas in the world (Fitzmaurice, 1993). It is a semi-enclosed, relatively shallow marine basin that captures and retains pollutants from numerous sources (HELCOM, 2010). During the last part of the $20^{\text {th }}$ century the Baltic Sea has been exposed to large anthropogenic pollutant loads (Vallius, 2015b). The Baltic breeding eider population has declined by over $30 \%$ since the 1990 s (Skov et al., 2011; Ekroos et al., 2012), and is considered endangered (Bird Life International, 2015). Main threats to this population include increased predation, human impact on marine habitats, oil pollution and changes in the quantity and/or quality of food 
resources (Ekroos et al., 2012; HELCOM, 2013). Environmental analyses performed in the 1990s revealed elevated element concentrations throughout the Baltic Sea (Borg and Jonsson, 1996; Leivuori, 1998; Vallius, 1999). During the same time period Hollmèn et al. (1998) reported toxic levels of $\mathrm{Se}$ and $\mathrm{Pb}$ in blood and liver tissue of Baltic eiders, and dead eiders were diagnosed with $\mathrm{Pb}$ poisoning. Furthermore, Franson et al. (2000) reported a negative correlation between blood Pb concentration and delta-aminolevulinic acid dehydratase (ALAD, linked to development of anemia) in Baltic eiders. These studies suggest that toxic element exposure has posed a real threat to Baltic eiders in the past. More recent sediment analyses in the Baltic Sea indicate that toxic element levels have declined significantly during the last two decades (Vallius, 2014). However, there are indications that levels of certain toxic elements, such as $\mathrm{Cd}, \mathrm{Cu}$ and $\mathrm{Hg}$ are still of concern in some areas of the Baltic Sea (Vallius, 2014; Vallius, 2015b). Thus, an updated documentation of toxic element concentrations in the Baltic Sea population of eiders is needed to assess the current toxic element exposure of this seabird population.

Compared to the Baltic Sea, Svalbard is considered a relatively clean area (Fenstad et al., 2016). However, sediment analyses indicate that there may be some $\mathrm{Cd}, \mathrm{Pb}$ and $\mathrm{Hg}$ pollution in regions of the Norwegian Arctic (Lu et al., 2013). The major input of toxic elements into the Arctic, however, results from transport from more industrialized areas (AMAP, 2005), and evidence suggests that $\mathrm{Hg}$ deposition in the Arctic may increase due to increased global emissions (Riget et al., 2011). In contrast to the Baltic Sea population, the Svalbard eider population has remained stable over the last three decades (Hanssen et al., 2013). Toxic element levels in Svalbard eiders have, to our knowledge, only been reported in tissues such as liver, 
kidney or muscle (Norheim and Kjos-Hanssen, 1984; Norheim and Borch-lohnsen, 1990; Savinov et al., 2003). The reported liver concentrations of Cd, Cu and Se in Svalbard eiders in the 1980s and 1990s were comparable with Baltic eiders, while liver $\mathrm{Hg}$ and possibly As concentrations appeared to be higher in Baltic eiders. Liver $\mathrm{Pb}$ concentrations have not been reported in Svalbard eiders (Norheim, 1987; Norheim and Borch-lohnsen, 1990; Hollmèn et al., 1998; Savinov et al., 2003). Sediment analysis from the Baltic Sea (Gulf of Finland) and Svalbard (Kongsfjorden) indicates that the concentrations of $\mathrm{Cd}$ and $\mathrm{Hg}$ are higher in the Baltic Sea compared to Svalbard, but for other toxic elements, sediment concentrations may be comparable between the two locations (Grotti et al., 2013; Lu et al., 2013; Vallius, 2009, 2015a).

The objectives of the present study were to determine and compare blood and feather concentrations of 8 elements in Baltic and Svalbard eiders. The blood element concentrations in Baltic eiders were also compared and evaluated in relation to previously reported blood concentrations in this population. Furthermore, the toxicological relevance of the blood element concentrations in the two populations was evaluated, based on previously reported adverse effects and threshold levels in birds.

Blood and underlying body feather samples were obtained from incubating female eiders in Tvärminne ( $\mathrm{N}=28)$, Finland $\left(\sim 59^{\circ} 84^{\prime} \mathrm{N}, 23^{\circ} 21^{\prime} \mathrm{E}\right)$ and at Storholmen, Kongsfjorden ( $\mathrm{N}=29)$, Svalbard $\left(78^{\circ} 56^{\prime} \mathrm{N}, 12^{\circ} 13^{\prime} \mathrm{E}\right)$, in 2011 . Baltic eiders migrate to Denmark, Germany and the Netherlands during winter (Lehikoinen et al., 2008), 
whereas Svalbard eiders migrate to Iceland and northern Norway (Figure 1) (Hanssen et al., 2016). Body feathers are likely moulted in these areas.

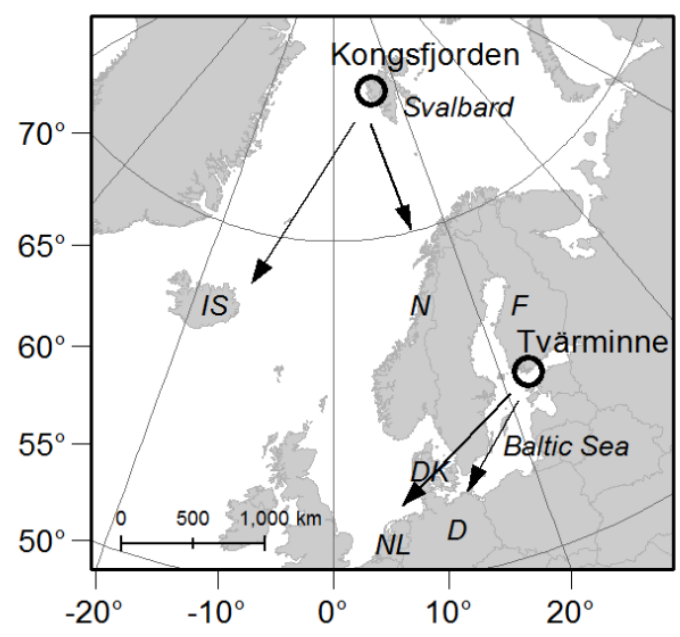

Figure 1: Breeding locations (circles) of the Svalbard (Kongsfjorden, $78^{\circ} 56^{\prime} \mathrm{N}$, $\left.12^{\circ} 13^{\prime} \mathrm{E}\right)$ and the Baltic (Tvärminne, Finland $\left.(\mathrm{F}), 59^{\circ} 84^{\prime} \mathrm{N}, 23^{\circ} 21^{\prime} \mathrm{E}\right)$ eider populations. Arrows show the wintering areas in Iceland (IS) and northern Norway (N) for the Svalbard eiders (Hanssen et al., 2016), and Denmark (DK), the Netherlands (NL) and Germany (D) for the Baltic eiders (Lehikoinen et al., 2008). The map is in a North Pole stereographic projection.

The females were caught on the nest using a fishing rod with a nylon snare at the end, or with hand-nets. Female eiders fast during their incubation period and incubation stage may affect blood levels of certain elements (Franson et al., 2000; Wayland and Scheuhammer, 2011). Thus, females were only sampled if the clutch had hatched or was near hatching based on egg floatation (Kilpi and Lindström, 1997). Body mass (to the nearest $10 \mathrm{~g}$ ) was recorded using a spring balance (Pesola Medio-Line 42500, Ecotone-Poland, $2500 \mathrm{~g})$. Blood (8-10 mL) was sampled from the 
jugular vein using a heparinised syringe. The blood was transported to the field station within six hours, and two $\mathrm{mL}$ whole blood was frozen $\left(-20^{\circ} \mathrm{C}\right)$ for subsequent element analyses. Underlying body feathers were sampled from the back of the females and packed in enclosed transparent plastic bags. Blood samples and feathers were transported to the laboratory at the Norwegian University of Science and Technology (NTNU), Trondheim, at the end of field season. The study complies with the Norwegian and Finnish regulation on animal experimentation, and permission for field work was granted by the Governor of Svalbard and the local authorities in Finland (Animal Experiment Board/State Provincial Office of Southern Finland, permit number ESLH-2009-02969/Ym-23).

Blood and feather samples were analysed for concentrations of the elements $\mathrm{Hg}$, $\mathrm{Se}, \mathrm{Pb}, \mathrm{Cd}, \mathrm{As}, \mathrm{Cr}, \mathrm{Zn}$ and $\mathrm{Cu}$ using High Resolution Inductively Coupled Plasma Mass Spectrometry (HR-ICP-MS, Thermo Electronic Corporation, Waltham, MA, USA) at the Department of Chemistry, NTNU.

For the detection of the elements, approximately $500 \mathrm{mg}$ blood was transferred to acid washed Teflon tubes, designed for UltraClave, and added to $0.5 \mathrm{~mL} 50 \%$ Scanpure nitric acid $\left(\mathrm{HNO}_{3}\right.$ ultra-pure grade, $\left.14.4 \mathrm{M}\right)$ for digestion. For the feather samples, approximately $30 \mathrm{mg}$ of feathers was added two $\mathrm{mL} 50 \% \mathrm{HNO}_{3}$ for digestion. The samples were digested using a high pressure microwave system, UltraClave (Milestone, Shelton, CT, USA) over two hours with temperature up to 240 ${ }^{\circ} \mathrm{C}$ and pressure of $160 \mathrm{bar}$. Blood samples were diluted to $12 \mathrm{~mL}$ and feather samples were diluted to $24 \mathrm{~mL}$ with ion exchanged Milli-Q-water before element analysis. 
To assure the quality of the analysis, four reference material samples (seronorm, Trace Elements Whole Blood L-1, LOT MR4206, REF 201505, Sero, Billingstad, Norway) were analysed with the blood samples. Also, four reference samples (tea leaves, GBW07601- GBW07605, Institute of Geophysical and Geochemical Exploration, Langfang, China) were analysed with the feather samples. Two replicates of four of the blood samples were analysed in different runs, and three blank samples accompanied every run of the analysis. The analysed reference material was within the approved range values for all analysed elements. The results were corrected from blank samples and the detection limits ranged between 1 - 200 $\mu \mathrm{g} / \mathrm{kg}$ for feathers and $0.02-3.6 \mu \mathrm{g} / \mathrm{kg}$ for blood for the analysed elements. Concentrations were above the detection limit, with the exception of four individuals with feather $\mathrm{Cr}$ concentrations and four individuals with blood $\mathrm{Cr}$ concentrations below the detection limit ( 6 and $0.1 \mu \mathrm{g} / \mathrm{kg}$, respectively). Negative $\mathrm{Cr}$ concentrations were set to zero, and positive Cr concentrations below the detection limit were set to $50 \%$ of the detection limit. Element concentrations are presented as $\mu \mathrm{g} / \mathrm{kg}$ wet weight (ww).

Statistical analyses were carried out using the programme $R$, version 3.2.3 ( $R$ Development Core Team., 2016). Separate linear models (Im function), with blood concentration as dependent variable, and population (factor with two levels, Baltic Sea and Svalbard), feather element concentration and female body mass as independent variables were used to test differences in blood concentrations between the two populations. The two latter covariates were included to test whether female body mass and feather element concentrations affected the concentrations of elements in blood. Independent variables with $p$ values $>0.1$ were removed from the 
starting model. Finally, separate linear models for each element, with feather element concentration as dependent variable and population as independent variable were used to test differences in feather concentrations between the two populations.

A Se rich diet can prevent toxic effects from Hg (Ralston et al., 2007; Sørmo et al., 2011) because Se binds and inactivates Hg (Dyrssen and Wedborg, 1991), and thereby counteracts its toxic effects (Sørmo et al., 2011; Mulder et al., 2012). The molar ratio between Se and $\mathrm{Hg}$ in blood was calculated for both eider populations.

Diagnostic plots in R (Residuals vs. Fitted, Normal QQ, Scale-Location and Residuals vs. Leverage plot) were used to assess whether the data sufficiently met the assumptions of a linear model (normal distribution of residuals, linearity, equal variance). All blood and feather concentrations, with the exception of feather concentration of $\mathrm{Cu}$, were $\log ^{\mathrm{e}}$-transformed prior to statistical analyses to satisfy the assumptions of parametric tests. All tests were two-tailed and significance was set at $\mathrm{p}<0.05$

Blood concentrations of $\mathrm{Hg}\left(\mathrm{t}_{55}=-4, \mathrm{p}=0.0001\right)$ were significantly higher in Baltic eiders compared to Svalbard eiders (Figure 2), whereas blood concentrations of Se $\left(t_{54}=6, p<0.0001\right)$, As $\left(t_{55}=3, p=0.005\right)$ and $C d\left(t_{54}=7, p<0.0001\right)$ were higher in Svalbard eiders. The blood concentrations of $\mathrm{Pb}\left(\mathrm{t}_{55}=1, \mathrm{p}=0.3\right), \mathrm{Cr}\left(\mathrm{t}_{54}=-0.5, \mathrm{p}\right.$ $=0.6), \mathrm{Zn}\left(\mathrm{t}_{54}=-1, \mathrm{p}=0.3\right)$ and $\mathrm{Cu}\left(\mathrm{t}_{54}=1, \mathrm{p}=0.3\right)$ did not differ between the two eider populations (Figure 2). Blood element concentrations were not affected by female body mass $(p>0.3)$, with the exception of a positive relationship between body mass and the blood concentration of $\mathrm{Cu}$ and $\mathrm{Zn}(\mathrm{p}<0.05)$. 
A)
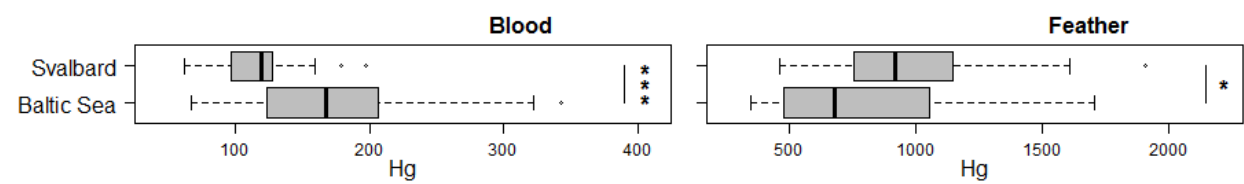

B)
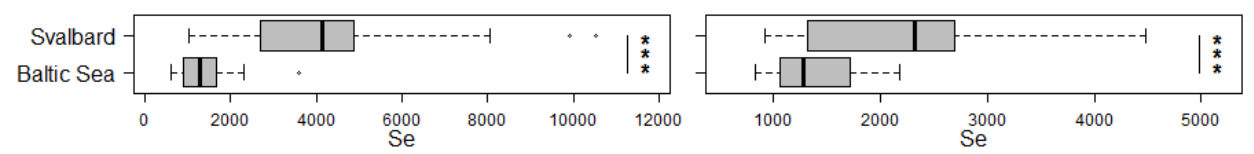

C)
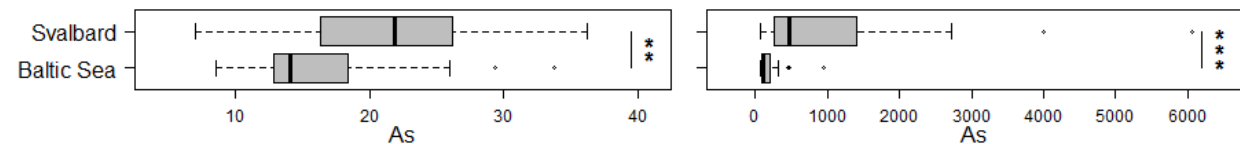

D)
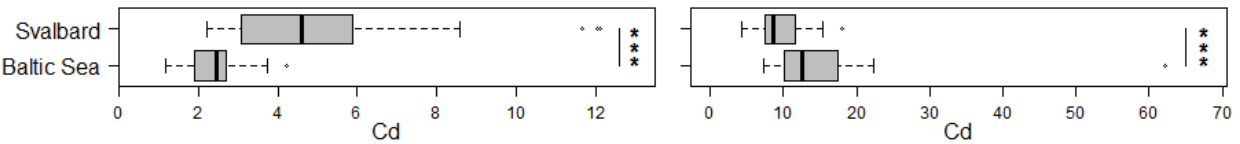

E)
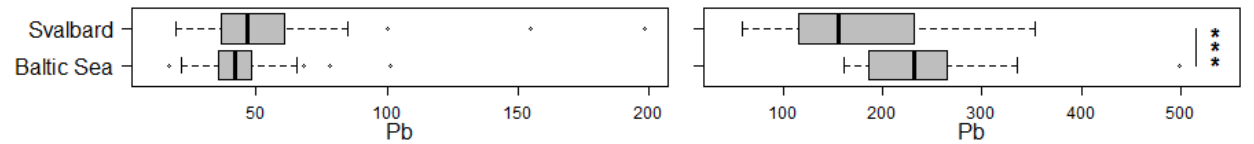

F) Svaltic Sea
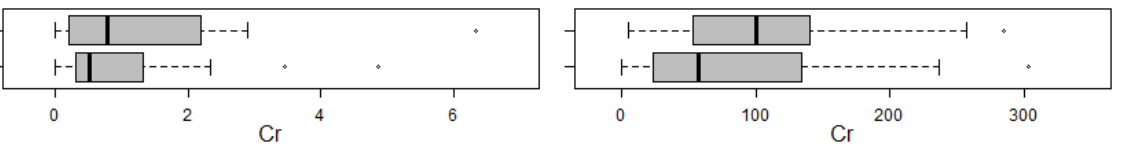

G)
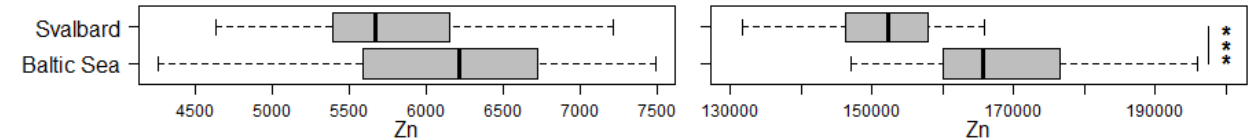

H)
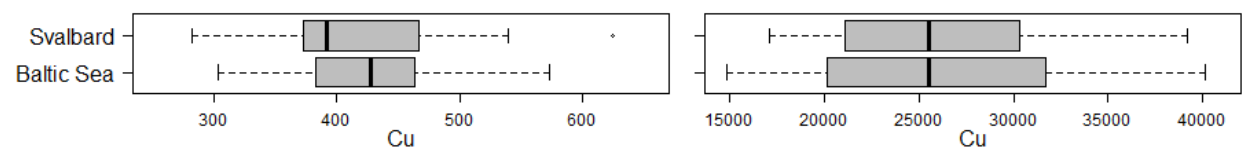

Figure 2: Box plots with blood (left) and feather (right) concentrations ( $\mu \mathrm{g} / \mathrm{kg} \mathrm{ww}$ ) of A) mercury (Hg), B) selenium (Se), C) arsenic (As), D) cadmium (Cd), E) lead (Pb), F) chromium ( $\mathrm{Cr}), \mathrm{G})$ zinc $(\mathrm{Zn})$ and $\mathrm{H})$ copper $(\mathrm{Cu})$ in female eiders from Svalbard (upper box) and the Baltic Sea (lower box). The plots show medians (thick vertical lines in boxes) along with the interquartile range (IQR, box), maximum and minimum values within 1.5 IQR (whiskers) and values outside IQR (outliers).

P-values from linear models (see text) are indicated by stars $\left({ }^{*}\right)$ to the right of the boxes, where $p<0.001$ is indicated by ${ }^{* *}, p<0.01$ by ${ }^{* *}$ and $p<0.5$ by *

The mean blood concentration of $\mathrm{Hg}$ was 1.5 times higher in the Baltic eiders than in the Svalbard eiders. The highest individual blood concentration of $\mathrm{Hg}$ in the Baltic 
population was $343 \mu \mathrm{g} / \mathrm{kg}$. Furthermore, the Svalbard eiders had three times higher mean blood concentrations of Se compared to the Baltic eiders. Thus, there were large differences in the molar relationships of $\mathrm{Se}$ and $\mathrm{Hg}$ in the two populations. While the Se:Hg molar ratio was $92(55: 0.6(\mu \mathrm{mol} / \mathrm{kg}))$ in blood of Svalbard eiders, it was $19(17: 0.9(\mu \mathrm{mol} / \mathrm{kg}))$ in the blood of Baltic eiders.

Inconsistent with blood concentrations (Figure 2), the feather concentrations of $\mathrm{Hg}$ $\left(t_{55}=2, p=0.047\right)$ were higher in Svalbard eiders than in Baltic eiders (Figure 2). Although blood concentrations of Cd were significantly higher in Svalbard $\left(\mathrm{t}_{54}=7, \mathrm{p}\right.$ $<0.0001)$, the feather concentrations were twice as high in Baltic eiders $\left(t_{55}=-4, p<\right.$ 0.0001). Furthermore, the feather concentrations of $\mathrm{Pb}$ were 1.4 times higher in Baltic eiders ( $\left.t_{55}=-4, p=0.0002\right)$, and feather concentrations of $Z n$ were 1.1 times higher in Baltic eiders compared to Svalbard eiders $\left(t_{55}=-5, p<0.0001\right)$ (Figure 2). Consistent with the patterns in blood, feather concentrations of Se $\left(t_{55}=4, p<\right.$ $0.0001)$ and $A s\left(t_{55}=6, p<0.0001\right)$ were higher in Svalbard compared to Baltic eiders (Figure 2). As for blood, there were no significant differences in the feather concentrations of $\mathrm{Cu}$ and $\mathrm{Cr}$ between the two populations ( $p>0.1$, Figure 2).

For Se ( $\left.t_{54}=4, p=0.01\right)$ and $\mathrm{Cr}\left(t_{54}=2, p=0.02\right)$, there was a significant positive correlation between the blood and feather concentration. However, for the remaining elements, blood and feather concentrations did not correlate with each other ( $p$ > $0.05)$

This study reports blood element concentrations from the Arctic eider population in Svalbard for the first time, and provides up-dated information on element exposure in the Baltic population, which was presumably exposed to potentially toxic concentrations in the 1990s (Hollmèn et al., 1998; Franson et al., 2000). The 
differences in blood and feather element concentrations between the two populations in the present study suggest different exposure patterns at the breeding and moulting locations of these two populations.

Blood concentrations of $\mathrm{Hg}$, Se, As and $\mathrm{Cd}$, indicating recent exposure, differed between the Baltic Sea and Svalbard eider populations. In accordance with reported sediment concentrations of elements at the two locations (Vallius 2009; Grotti et al., 2013; Lu et al., 2013; Vallius 2015a), blood concentrations of Hg were significantly higher in Baltic eiders compared to Svalbard eiders. This is consistent with previous reports indicating that $\mathrm{Hg}$ levels in Baltic biota, such as in fish and blue mussels (Mytilus edulis), are far above the assumed threshold levels for natural background concentrations, associated with non-polluted areas (HELCOM, 2010). The blood concentrations of $\mathrm{Hg}$ in the Baltic eiders were comparable to those reported in eiders from the same location in 1997 and 1998 (maximum concentration of $0.22-0.31$ ppm (= $220-310 \mu \mathrm{g} / \mathrm{kg}$ ww) (Franson et al., 2000; Hollmèn et al., 1998), suggesting that the bioavailable environmental concentrations of $\mathrm{Hg}$ in the Baltic Sea have not declined during the last two decades. The blood $\mathrm{Hg}$ concentrations in Baltic eiders $(67-343 \mu \mathrm{g} / \mathrm{kg})$ were in the same range as in eiders in the Canadian Arctic in 1998 $(140-370 \mu \mathrm{g} / \mathrm{kg})$ (Wayland et al., 2001), whereas the blood concentrations in the Svalbard eiders were lower $(62-197 \mu \mathrm{g} / \mathrm{kg})$. Because there are few reports on blood concentrations of toxic elements in eiders, it is not possible to apply results from the present study to provide a more comprehensive overview of spatial variation in $\mathrm{Hg}$ levels in arctic eider populations. However, in a recent study, Lovvorn et al. (2013) summed up previously reported hepatic Hg concentrations in eiders from Svalbard, Western Greenland, East Canada and Finland. Although these data 
originate from the 1980s, these results indicate that during this period, $\mathrm{Hg}$ concentrations were lowest in the East Canadian Arctic (Wayland et al., 2001) and Svalbard (Savinov et al., 2003), intermediate in eiders from Western Greenland (Dietz et al., 1996), and highest in eiders from Finland (Hollmen et al., 1998).

Contrary to $\mathrm{Hg}$, blood concentrations of $\mathrm{Cd}$, Se and As were greater in Svalbard compared to Baltic eiders. Reported sediment concentrations from relevant locations in the Baltic Sea and Svalbard might indicate that exposure levels to Cd are higher in the Baltic Sea (Vallius 2009; Grotti et al., 2013; Lu et al., 2013; Vallius 2015a). Furthermore, in most sites in the Baltic Sea, Cd concentrations in blue mussel are higher than the estimated natural background levels associated with no anthropogenic pollution (HELCOM, 2010). Nevertheless, blood Cd concentrations in both eider populations were far below the blood levels suggested to be caused by exposure to natural background Cd levels $(<26 \mu \mathrm{g} / \mathrm{dl}(\sim 260 \mu \mathrm{g} / \mathrm{kg})($ Cutnell and Johnson, 2004)), and in accordance with the commonly reported blood concentrations of Cd $(<5 \mathrm{ng} / \mathrm{mL})$ in wild birds (Wayland and Scheuhammer, 2011).

Blood concentrations of $\mathrm{Se}$ in both eider populations were comparable to those reported in the Baltic eiders in the 1990s $(1180-3390 \mu \mathrm{g} / \mathrm{kg}$ ww and $300-9250$ $\mu \mathrm{g} / \mathrm{kg} \mathrm{ww}$ ) (Hollmèn et al., 1998; Franson et al., 2000). Although Se concentrations below $0.4 \mathrm{mg} / \mathrm{L}$ ww ( $0.4 \mathrm{mg} / \mathrm{kg}(400 \mu \mathrm{g} / \mathrm{kg})$ (Cutnell and Johnson, 2004)) are considered to represent background levels in whole blood of non-marine birds, marine birds in non-polluted areas tend to have greater Se concentrations in their blood (Harry and Gary, 2011).

Blood concentrations of As were higher in Svalbard compared to Baltic eiders. However, As levels tend to be higher in marine organisms (Kunito et al., 2008), and the Baltic eiders may have lower concentrations because they feed in brackish 
water. The majority of avian studies reporting As levels have focused on tissue levels (Eisler, 2010; Sanchez-Virosta et al., 2015).

Blood concentrations of $\mathrm{Pb}, \mathrm{Cr}, \mathrm{Zn}$ and $\mathrm{Cu}$ did not differ between the two eider populations. Blood $\mathrm{Pb}$ concentrations in the present study were comparable to the lowest blood concentrations measured in Baltic eiders in 1997 and 1998 (20 - 520

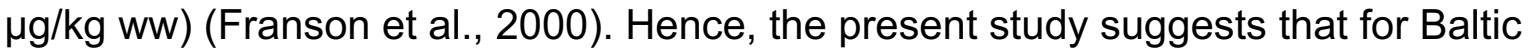
eiders the exposure to $\mathrm{Pb}$ has decreased during the last two decades. Lead additives in petroleum has been the major source of atmospheric $\mathrm{Pb}$ and contributed significantly to $\mathrm{Pb}$ levels in biota (Tong et al., 2000). Lead additives in petroleum were phased out during the 1990s, and completely prohibited in the European Union by 2005 (EU, 1998). Furthermore, a total ban of lead shots in waterfowl hunting in Finland was introduced in 1996 (Avery and Watson, 2009). Thus, exposure to Pb in Baltic eiders has likely decreased due to both reduced emissions of $\mathrm{Pb}$ containing petroleum products and legislative restrictions on the use of lead ammunition during the last two decades, with a concomitant decrease in blood concentrations of $\mathrm{Pb}$.

There are limited published data on blood concentrations of $\mathrm{Cr}$ and $\mathrm{Zn}$ in different waterbird species (Eisler, 2010; Binkowski and Meissner, 2013). The blood concentrations of $\mathrm{Cr}$ in Svalbard and Baltic eiders were lower than in mallards (Anas platyrhynchos) from urban areas in Poland (0-0.4 $\mu \mathrm{g} / \mathrm{g}$ ww, (Binkowski and Meissner, 2013)), suggesting that Baltic and Svalbard eiders are likely not exposed to high levels of $\mathrm{Cr}$. The blood concentrations of $\mathrm{Zn}$ in Baltic and Svalbard eiders were generally higher than the blood concentrations reported in 11 wild waterbird species in the area around Doñana National Park, Spain, following a toxic spill from the Aznalcóllar mine $(0.3-8.6 \mathrm{mg} / \mathrm{L}$ (Benito et al., 1999)= $300-8600 \mu \mathrm{g} / \mathrm{kg}$ (Cutnell 
and Johnson, 2004)), but lower than in the blood of a Baltic top predator, the white tailed eagle in the 1980s (Haliaeetus albicilla, $7500 \mu \mathrm{g} / \mathrm{kg}$ (Falandysz et al., 1988)).

Reference plasma Cu concentrations of non-exposed birds have been suggested to range between $0.07-0.19$ ppm (Osofsky et al., 2001). Red blood cell concentration of $\mathrm{Cu}$ in birds may be approximately 3 times that of plasma concentrations (Evans and Wiederanders, 1967). Hence, blood Cu concentrations of Baltic and Svalbard eiders were comparable to the suggested reference levels of non-exposed birds of approximately $200-600 \mu \mathrm{g} / \mathrm{kg}$ (Osofsky et al., 2001).

In eiders, flight feathers are replaced once a year, and the moulting of body feathers is divided into pre-nuptial body moult and post-nuptial body moult. The female pre-nuptial moult may extend until March, depending on latitude (Waltho and Coulson, 2015). The feather is connected to blood vessels during growth and may ideally be used to indicate circulating concentrations of elements at feather formation (Burger and Gochfeld, 1992; Markowski et al., 2013). However, external contamination of certain elements may occur (Appelquist et al., 1984; Goede and de Bruin, 1984; Weyers et al., 1988), at least on the exposed outermost feathers (Jaspers et al., 2004). Secretion products from the birds, such as preening oils, might also contribute to the element concentrations measured in feathers (Goede and de Bruin, 1984; Pilastro et al., 1993). Although the feathers were not washed before analysis, external atmospheric contamination has likely not contributed extensively in the present study, as underlying, hidden body feathers were collected, and we have no reason to expect any systematic bias due to potential external atmospheric contamination of feather samples. 
Contrary to the pattern in blood, $\mathrm{Hg}$ concentrations were slightly, but significantly $(p=0.047)$ higher in feathers of Svalbard eiders, and Cd concentrations were twice as high in feathers of Baltic eiders (Figure 2). Furthermore, feather concentrations of $\mathrm{Pb}$ and $\mathrm{Zn}$ were significantly higher in Baltic eiders, although the blood concentration of $\mathrm{Pb}$ and $\mathrm{Zn}$ did not differ between the two populations. Thus, the differences in the element concentrations in blood and feathers within the two populations, suggest that exposure to $\mathrm{Hg}$ may be greater in Svalbard eiders during moulting, while body burden and exposure to $\mathrm{Cd}, \mathrm{Pb}$ and $\mathrm{Zn}$ may be greater in Baltic eiders during moulting. Hence, the present study clearly indicates that these eiders breed and moult at different locations, which expose them to seasonally variable loads of toxic elements. It should also be noted that the $\mathrm{Hg}$ concentrations in the body feathers of the present eiders (Baltic: $0.3-1.7 \mu \mathrm{g} / \mathrm{g}$, Svalbard: $0.5-1.9 \mu \mathrm{g} / \mathrm{g}$ ) were somewhat higher than reported in primary feathers of eiders from the Canadian Arctic (0.24 $0.95 \mu \mathrm{g} / \mathrm{kg}$ ) (Mallory et al., 2015). Although this difference may be due to the different feather-types analysed, it may indicate that eiders from the Canadian Arctic winter in regions with less bioavailable $\mathrm{Hg}$ than the Svalbard and Baltic eiders.

Although adverse effect thresholds for $\mathrm{Hg}$ in blood of sea ducks have not been determined (Meattey et al., 2014), the concentrations in the present study (62 - 343 $\mu \mathrm{g} / \mathrm{kg} \mathrm{ww}$ ) were lower than most previously reported threshold concentrations for toxic effects in birds (Wolfe et al., 1998; Scheuhammer et al., 2007). For instance, $700 \mu \mathrm{g} / \mathrm{kg}$ and $3000 \mu \mathrm{g} / \mathrm{kg}$ ww resulted in reproductive effects in common loons (Gavia immer) (Evers et al., 2008) and Carolina wrens (Thryothorus ludovicianus), respectively. However, in a recent study, Espin et al. (2014b) found large increases in lipid peroxidation at blood concentrations of 3 and $10 \mu \mathrm{g} / \mathrm{dl} \mathrm{ww}(\sim 30$ and $\sim 100$ 
$\mu \mathrm{g} / \mathrm{kg}$ (Cutnell and Johnson, 2004)) in eagle owls (Bubo bubo). Furthermore, in griffon vultures (Gyps fulvus), blood Hg concentrations of $3 \mu \mathrm{g} / \mathrm{dl} w \mathrm{w}(\sim 30 \mu \mathrm{g} / \mathrm{kg}$ (Cutnell and Johnson, 2004)) were associated with a $10 \%$ increase in superoxide dismutase (SOD) activity (Espín et al., 2014a). Thus, in particular Baltic eiders, with greater blood $\mathrm{Hg}$ concentrations than Svalbard eiders, may risk adverse oxidative effects from $\mathrm{Hg}$ exposure.

The toxic interactions between Se and $\mathrm{Hg}$ are complex and not well understood (Shore et al., 2011). Evidence suggests that correlations between Se and $\mathrm{Hg}$, and Se protection from $\mathrm{Hg}$ toxicity, at least in tissue, are only relevant for the most exposed seabird species where Se:Hg molar ratios approach 1 (Kim et al., 1996). The blood molar relationship between Se and $\mathrm{Hg}$ was 92 in Svalbard eiders compared to 19 in Baltic eiders. However, $\mathrm{Hg}$ sensitivity varies between avian species (Heinz et al., 2009), and the sensitivity of eiders to Hg compared to other seabird species is unknown (Meattey et al., 2014). Thus, potential effects from $\mathrm{Hg}$ exposure in eiders warrants further studies.

Although Se may protect against the adverse effects of $\mathrm{Hg}$ and is an essential element, high Se concentrations may be toxic (Harry and Gary, 2011). Both eider populations had blood Se concentrations considered adequate for nutritional needs in birds (0.13-0.20 mg/kg ww) (Harry and Gary, 2011), and were therefore not at risk of Se depletion. Although Hollmén et al. (1998) reported similar blood Se concentrations in eiders to be potentially toxic, blood Se concentrations of Baltic and Svalbard eiders were below most reported blood concentrations causing effects on adult survival, body mass or breeding probability in experimental studies on birds (Harry and Gary, 2011). Furthermore, no correlations were found between blood Se concentrations and survival in eiders from Alaska (Wilson et al., 2007), where blood 
levels tended to be higher than in the present study $(1500-15700 \mu \mathrm{g} / \mathrm{kg} \mathrm{ww}$ vs. $600-$ $10500 \mu \mathrm{g} / \mathrm{kg} \mathrm{ww}$ ). In that particular study it was suggested that eiders living in environments with high Se exposure may have higher Se tolerance. In addition, eiders also appear to be more tolerant to Se than other waterbirds, such as mallards (Harry and Gary, 2011). Hence, Svalbard and Baltic eiders are likely not exposed to toxic levels of Se.

A blood $\mathrm{Pb}$ concentration $\geq 200 \mu \mathrm{g} / \mathrm{kg}$ is considered above the background level, based on concentrations in non-exposed wild birds and on the concentrations at which clinical effects and mortality may occur (Sanderson and Bellrose, 1986; Franson and Deborah, 2011). A blood Pb concentration of $500 \mu \mathrm{g} / \mathrm{kg}$ is considered sub-lethal but toxic (Sanderson and Bellrose, 1986; Franson and Deborah, 2011). Inhibition of ALAD in birds has been reported at blood $\mathrm{Pb}$ concentrations of $50 \mu \mathrm{g} / \mathrm{kg}$ (Franson and Deborah, 2011). Five of the 28 Baltic eiders and 13 of the 29 Svalbard eiders had $\mathrm{Pb}$ concentrations above $50 \mu \mathrm{g} / \mathrm{kg}$. It has been estimated that concentrations of $150-200 \mu \mathrm{g} \mathrm{Pb} / \mathrm{kg}$ lead to a reduction in ALAD activity by $50 \%$ (Franson and Deborah, 2011). In the present study, two of the 29 Svalbard eiders had concentrations within this range. Although the current blood concentrations of $\mathrm{Pb}$ were below these toxic threshold levels in most individuals from both populations, almost $50 \%$ of the Svalbard eiders had concentrations that were higher than the lowest threshold level. This may indicate that $\mathrm{Pb}$ levels are close to threshold levels for ALAD inhibition in both populations. However, birds appear to have some tolerance for ALAD inhibition before a reduction in haemoglobin concentration occurs (Franson and Deborah, 2011). In the study of Franson et al. (2000), the maximum blood concentration of Baltic eiders was $520 \mu \mathrm{g} / \mathrm{kg} \mathrm{ww}$, indicating that eiders sampled at that time had blood concentrations of $\mathrm{Pb}$ above background, and that 
some females were also in danger of $\mathrm{Pb}$ poisoning. Although $\mathrm{Pb}$ levels have decreased since the 1990s, and most of the Baltic and Svalbard eiders are currently not at risk of $\mathrm{Pb}$ poisoning, more research may be needed to conclude on the potential effects of $\mathrm{Pb}$ on ALAD inhibition in these eiders.

Cadmium accumulates in the liver and kidney of birds, and these are the tissues for which there is most information available on concentration-effect relationships (Wayland and Scheuhammer, 2011). Furthermore, Cd has no known toxicity threshold in avian blood (Wayland et al., 2008). In North American white-winged scoters (Melanitta fusca, 0.3-30.7 ng/mL ( 0.3-30.7 $\mu \mathrm{g} / \mathrm{kg}))$ and king eiders (Somateria spectabilis, 2-76 ng/mL), no relationship was, however, found between blood levels of Cd and survival (Wayland et al., 2007; Wayland et al., 2008). Hence, Svalbard and Baltic eiders are exposed to low levels of $\mathrm{Cd}$ and are likely not at risk of toxic effects.

Evaluating the toxicity relevance of blood $\mathrm{As}, \mathrm{Zn}$ and $\mathrm{Cu}$ concentrations is difficult because little data exist, and experimental studies with birds have not reported blood levels (Eisler, 1993; Osofsky et al., 2001; Eisler, 2010; Sanchez-Virosta et al., 2015). Zinc poisoning has, however, been documented in birds, but usually as a direct result of ingesting Zn containing products (Eisler, 1993). Plasma concentrations after poisoning with $\mathrm{Zn}$ were as high as $15.5 \mathrm{mg} / \mathrm{L}(\sim 15500 \mu \mathrm{g} / \mathrm{kg}$, (Eisler, 1993; Cutnell and Johnson, 2004), which is twice as high as the highest $\mathrm{Zn}$ concentration in whole blood in eiders in the present study.

In summary, Baltic and Svalbard eiders are exposed to element levels below the blood concentrations associated with toxic effects in birds. The present study also suggests that in general, element exposure has declined in the Baltic Sea since the 1990s. However, Hg exposure apparently remains similar in Baltic eiders, and the 
blood concentrations of $\mathrm{Hg}$ exceed thresholds for adverse oxidative effects reported in other avian species. The contrasting patterns between blood and feather concentrations of particularly $\mathrm{Hg}$ and $\mathrm{Cd}$, however, emphasize the need for yearround monitoring of exposure to elements to comprehensively assess toxic element status.

Acknowledgments

This work was supported by a PhD fellowship provided by the Faculty of Natural Sciences and Technology (70201200), Norwegian University of Science and Technology. Arctic Field Grants from Svalbard Science Forum (2011) financed the field work in Svalbard. We thank the staff at Sverdrup Station, Ny-Ålesund and Tvärminne Zoological Station, Finland, for logistic support. The work in Finland was founded by the Academy of Finland (grant No. 128039 to MÖ and 266208 to KJ) and the Swedish Cultural Foundation in Finland (to MÖ). Finally, we thank Kong Haakon den 7des utdanningsfond for norsk ungdom (University of Troms $\varnothing$, Norway) for financial support.

References

AMAP, 2005. AMAP Assessment 2002: Heavy metals in the arctic. Arctic monitoring and assessment programme (AMAP), Oslo, Norway, p. xvi + 265 pp.

Appelquist, H., Asbirk, S., Drabæk, I., 1984. Mercury monitoring: Mercury stability in bird feathers. Mar. Pollut. Bull. 15, 22-24.

Avery, D., Watson, R.T., 2009. Regulation of lead-based ammunition around the world. In: Ingestion of lead from spent ammunition: Implications for wildlife and humans. The Peregrine Fund, Boise, Idaho, USA.

Benito, V., Devesa, V., Muñoz, O., Suñer, M.A., Montoro, R., Baos, R., Hiraldo, F., Ferrer, M., Fernández, M., González, M.J., 1999. Trace elements in blood collected from birds feeding in the area around Doñana National Park affected by the toxic spill from the Aznalcóllar mine. Sci. Total Environ. 242, 309-323.

Binkowski, Ł.J., Meissner, W., 2013. Levels of metals in blood samples from Mallards (Anas platyrhynchos) from urban areas in Poland. Environ. Pollut. 178, 336-342.

Bird Life International, 2015. European red list of birds. Available at: http://birdlife.org/datazone/info/euroredlistcom. Vol. 2016, 2015.

Borg, H., Jonsson, P., 1996. Large-scale metal distribution in Baltic Sea sediments. Mar. Pollut. Bull. 32, 8-21. 
Burger, J., Gochfeld, M., 1992. Trace element distribution in growing feathers: Additional excretion in feather sheaths. Arch. Environ. Contam. Toxicol. 23, 105-108.

Burger, J., Gochfeld, M., 2009. Mercury and other metals in feathers of common eider (Somateria mollissima) and tufted puffin (Fratercula cirrhata) from the Aleutian Chain of Alaska. Arch. Environ. Contam. Toxicol. 56, 596-606.

Croxall, J.P., Butchart, S.H.M., Lascelles, B., Stattersfield, A.J., Sullivan, B., Symes, A., Taylor, P., 2012. Seabird conservation status, threats and priority actions: a global assessment. Bird Conservation International 22, 1-34.

Cutnell, J.D., Johnson, K.W., 2004. Fluids In: Physics, 6 ed. John Whiley and Sons, Inc, USA.

Dietz, R., Riget, F., Johansen, P., 1996. Lead, cadmium, mercury and selenium in greenland marine animals, Sci. Total Environ. 186:67-93.

Dyrssen, D., Wedborg, M., 1991. The sulphur-mercury(II) system in natural waters. Water, Air, Soil Pollut. 56, 507-519.

Eisler, R., 1993. Zinc Hazards to fish, wildlife, and invertebrates: A synoptic review, Contaminant Hazard Reviews, Laurel, MD.

Eisler, R., 2010. Chapter 5 - Birds, compendium of trace metals and marine biota. Elsevier, Amsterdam, pp. 253-361.

Ekroos, J., Fox, A.D., Christensen, T.K., Petersen, I.K., Kilpi, M., Jónsson, J.E., Green, M., Laursen, K., Cervencl, A., de Boer, P., Nilsson, L.W., Meissner, o., Garthe, S., Öst, M., 2012. Declines amongst breeding eider Somateria mollissima numbers in the Baltic/Wadden Sea flyway. Ornis Fennica 89, 8190.Espín, S., Martínez-López, E., Jiménez, P., María-Mojica, P., GarcíaFernández,

A.J., 2014a. Effects of heavy metals on biomarkers for oxidative stress in Griffon vulture (Gyps fulvus). Environ. Res. 129, 59-68.

Espín, S., Martínez-López, E., León-Ortega, M., Martínez, J.E., García-Fernández, A.J., 2014b. Oxidative stress biomarkers in eurasian eagle owls (Bubo bubo) in three different scenarios of heavy metal exposure. Environ. Res. 131, 134144.

EU, 1998. EC of the European Parliament and of the Council of 13 October 1998 relating to the quality of petrol and diesel fuels and amending Council Directive 93/12/EEC. Directive.

Evans, G.W., Wiederanders, R.E., 1967. Blood copper variation among species. Am. J. Physiol. 213, 1183-1185.

Evers, D.C., Savoy, L.J., DeSorbo, C.R., Yates, D.E., Hanson, W., Taylor, K.M., Siegel, L.S., Cooley, J.H., Bank, M.S., Major, A., Munney, K., Mower, B.F., Vogel, H.S., Schoch, N., Pokras, M., Goodale, M.W., Fair, J., 2008. Adverse effects from environmental mercury loads on breeding common loons. Ecotoxicology 17, 69-81.

Falandysz, J., Jakuczun, B., Mizera, T., 1988. Metals and organochlorines in four female White-tailed eagles. Mar. Pollut. Bull. 19, 521-526.

Fenstad, A.A., Jenssen, B.M., Gabrielsen, K.M., Öst, M., Jaatinen, K., Bustnes, J.O., Hanssen, S.A., Moe, B., Herzke, D., Krøkje, Å., 2016. Persistent organic pollutant levels and the importance of source proximity in Baltic and Svalbard breeding common eiders. Environ. Toxicol. Chem.. doi: 10.1002/etc.3303.

Fitzmaurice, M., 1993. The new Helsinki convention on the protection of the marine environment of the Baltic Sea area. Mar. Pollut. Bull. 26, 64-67.

Franson, J.C., Deborah, J.P., 2011. Lead in birds, environmental contaminants in 
biota. CRC Press, pp. 563-593.

Franson, J.C., Hollmen, T., Poppenga, R.H., Hario, M., Kilpi, M., Smith, M.R., 2000.

Selected trace elements and organochlorines: Some findings in blood and eggs of nesting common eiders (Somateria mollissima) from Finland. Environ.

Toxicol. Chem. 19, 1340-1347.

Franson, J.C., Hollmén, T.E., Flint, P.L., Grand, J.B., Lanctot, R.B., 2004.

Contaminants in molting long-tailed ducks and nesting common eiders in the Beaufort Sea. Mar. Pollut. Bull. 48, 504-513.

Garcá-Fernández, A.J., Sanchez-Garcia, J.A., Gomez-Zapata, M., Luna, A., 1996. Distribution of cadmium in blood and tissues of wild birds. Arch. Environ. Contam. Toxicol. 30, 252-258.

Goede, A.A., de Bruin, M., 1984. The use of bird feather parts as a monitor for metal pollution. Environ. Pollut., Ser. B 8, 281-298.

Goodale, M.W., Evers, D.C., Mierzykowski, S.E., Bond, A.L., Burgess, N.M., Otorowski, C.I., Welch, L.J., Hall, C.S., Ellis, J.C., Allen, R.B., Diamond, A.W., Kress, S.W., Taylor, R.J., 2008. Marine forarging birds as bioindicators for mercury in the Gulf of Main, Ecohealth 5, 409-425.

Grotti, M., Soggia, F., Ianni, C., Magi, E., Udisti, R., 2013. Bioavailability of trace elements in surface sediments from Kongsfjorden, Svalbard. Mar. Pollut. Bull. 77, 367-374.

Hanssen, S.A., Gabrielsen, G.W., Bustnes, J.O., Sandøy, V.B., Skottene Elise, Fenstad Anette A., Strøm Hallvard, Bakken Vidar, Phillips Richard A., Børge., M., 2016. Migration strategies of common eiders from Svalbard: implications for bilateral conservation management. Polar Biol., 1-10.

Hanssen, S.A., Moe, B., Bardsen, B.J., Hanssen, F., Gabrielsen, G.W., 2013. A natural antipredation experiment: predator control and reduced sea ice increases colony size in a long-lived duck. Ecol. Evol. 3, 3554-3564.

Harry, M.O., Gary, H.H., 2011. Selenium in birds, environmental contaminants in biota. CRC Press, pp. 669-701.

Heinz, G.H., Hoffman, D.J., Klimstra, J.D., Stebbins, K.R., Kondrad, S.L., Erwin, C.A., 2009. Species differences in the sensitivity of avian embryos to methylmercury. Arch. Environ. Contam. Toxicol. 56, 129-138.

HELCOM, 2010. Hazardous substances in the Baltic Sea -An integrated thematic assessment of hazordous substances in the Baltic Sea. Executive summary. Balt. Sea Environ. Helsinki Commission, Helsinki.

HELCOM, 2013. HELCOM Red list of Baltic Sea species in danger of becoming extinct., Balt. Sea Environ.

Henny, C.J., Rudis, D.D., Roffe, T.J., Robinson-Wilson, E., 1995. Contaminants and sea ducks in Alaska and the circumpolar region. Environ. Health Perspect. 4, 41-49.

Hollmèn, T., Franson C.J., Poppenga, R.H., Hario, M., Kilpi., M., 1998. Lead poisoning and trace elements in common eiders Somateria Mollissima from Finland. Wildlife Biology 4, 193-203.

Jaspers, V., Dauwe, T., Pinxten, R., Bervoets, L., Blust, R., Eens, M., 2004. The importance of exogenous contamination on heavy metal levels in bird feathers. A field experiment with free-living great tits, Parus major. J. Environ. Monit. 6, 356-360.

Kilpi, M., Lindström, K., 1997. Habitat-specific clutch size and cost of incubation in common eiders, Somateria mollissima. Oecologia 111, 297-301.

Kim, E.Y., Saeki, K., Tanabe, S., Tanaka, H., Tatsukawa, R., 1996. Specific 
accumulation of mercury and selenium in seabirds. Environ. Pollut. 94, 261265.

Koivula, M.J., Eeva, T., 2010. Metal-related oxidative stress in birds. Environ. Pollut. 158, 2359-2370.

Kunito, T., Kubota, R., Fujihara, J., Agusa, T., Tanabe, S., 2008. Arsenic in marine mammals, seabirds, and sea turtles, Rev. Environ. Contam. Toxicol.. Springer Omaha, USA.

Lehikoinen, A., Christensen, T.K., Öst, M., Kilpi, M., Saurola, P., Vattulainen, A., 2008. Large-scale change in the sex ratio of a declining eider Somateria mollissima population. Wildlife Biology 14, 288-301.

Leivuori, M., 1998. Heavy metal contamination in surface sediments in the Gulf of Finland and comparison with the Gulf of Bothnia. Chemosphere 36, 43-59.

Lovvorn, J.R., Raisbeck, M.F., Cooper, L.W., Cutter, G.A., Miller, M.W., Brooks, M.L., Grebemeier, J.M., Matz, A.C., Schaefer, C.M., 2013. Wintering eiders acquire exceptional Se and $\mathrm{Cd}$ burdens in the Bering Sea: physiological and oceanographic factors. Mar. Ecol-Prog. Ser. 489:245+.

Lu, Z., Cai, M., Wang, J., Yin, Z., Yang, H., 2013. Levels and distribution of trace metals in surface sediments from Kongsfjorden, Svalbard, Norwegian Arctic. Environ. Geochem. Health 35, 257-269.

Mallory, M.L., Braune, B.M., Provencher, J.F., Callaghan, D.B., Gilchrist, H.G., Edmonds, S.T., Allard, K., O'Driscoll, N.J., 2015. Mercury concentrations in feathers of marine birds in Arctic Canada. Mar. Pollut. Bull. 98:308-313.

Markowski, M., Kalinski, A., Skwarska, J., Wawrzyniak, J., Banbura, M., Markowski, J., Zielinski, P., Banbura, J., 2013. Avian feathers as bioindicators of the exposure to heavy metal contamination of food. Bull. Environ. Contam. Toxicol. 91, 302-305.

Meattey, D.E., Savoy, L., Beuth, J., Pau, N., O'Brien, K., Osenkowski, J., Regan, K., Lasorsa, B., Johnson, I., 2014. Elevated mercury levels in a wintering population of common eiders (Somateria mollissima) in the northeastern United States. Mar. Pollut. Bull. 86, 229-237.

Mulder, P.J., Lie, E., Eggen, G.S., Ciesielski, T.M., Berg, T., Skaare, J.U., Jenssen, B.M., Sørmo, E.G., 2012. Mercury in molar excess of selenium interferes with thyroid hormone function in free-ranging freshwater fish. Environ. Sci. Technol. 46, 9027-9037.

Nordberg, G.F., Fowler, B.A., Nordberg, M., 2014. Handbook on the toxicology of metals, 4 ed. Elsevier, Oxford, UK.

Norheim, G., 1987. Levels and interactions of heavy metals in sea birds from Svalbard and the Antarctic. Environ. Pollut. 47, 83-94.

Norheim, G., Borch-lohnsen, B., 1990. Chemical and morphological studies of liver from eider (Somateria mollissima) in Svalbard with special reference to the distribution of copper. J. Comp. Pathol. 102, 457-466.

Norheim, G., Kjos-Hanssen, B., 1984. Persistent chlorinated hydrocarbons and mercury in birds caught off the west coast of Spitsbergen. Environ. Pollut. Ser. A, Ecol. Biol. 33, 143-152.

Osofsky, A., Jowett, P.L.H., Hosgood, G., Tully, T.N., 2001. Determination of normal blood concentrations of lead, zinc, copper, and iron in hispaniolan amazon parrots (Amazona ventralis). Journal of Avian Medicine and Surgery 15, 3136.

Pilastro, A., Congiu, L., Tallandini, L., Turchetto, M., 1993. The use of bird feathers 
for the monitoring of cadmium pollution. Arch. Environ. Contam. Toxicol. 24, 355-358.

Provencher, j.f., 2014. How arctic marine birds help researchers study a changing North. Arctic 67:564-569.

Ralston, N.V., Blackwell, J.L., 3rd, Raymond, L.J., 2007. Importance of molar ratios in selenium-dependent protection against methylmercury toxicity. Biol. Trace Elem. Res. 119, 255-268.

R Developmen Core Team., 2016. R: A language and environment for statistical computing. R Foundation for Statistical Computing.

Riget, F., Braune, B., Bignert, A., Wilson, S., Aars, J., Born, E., Dam, M., Dietz, R., Evans, M., Evans, T., Gamberg, M., Gantner, N., Green, N., Gunnlaugsdottir, H., Kannan, K., Letcher, R., Muir, D., Roach, P., Sonne, C., Stern, G., Wiig, O., 2011. Temporal trends of $\mathrm{Hg}$ in Arctic biota, an update. Sci. Total Environ. 409, 3520-3526.

Sanchez-Virosta, P., Espin, S., Garcia-Fernandez, A.J., Eeva, T., 2015. A review on exposure and effects of arsenic in passerine birds. Sci. Total Environ. 513, 506-525.

Sanderson, G.C., Bellrose, F.C., 1986. A Review of the problem of lead poisoning in waterfowl, Illinois natural history survey. Jamestown ND: Northern Prairie Wildlife Research Center Online. http://www.npwrc.usgs.gov/resource/birds/pbpoison/index.htm, Champaign, Illinois, p. 34.

Savinov, V.M., Gabrielsen, G.W., Savinova, T.N., 2003. Cadmium, zinc, copper, arsenic, selenium and mercury in seabirds from the Barents Sea: levels, interspecific and geographical differences. Sci. Total Environ. 306, 133-158.

Scheuhammer, A.M., Meyer, M.W., Sandheinrich, M.B., Murray, M.W., 2007. Effects of environmental methylmercury on the health of wild birds, mammals, and fish. Ambio 36, 12-18.

Shore, R.F., Pereira, M.G., Woshner, V., Thompson, D.R., 2011. Mercury in nonmarine birds and mammals, environmental contaminants in biota:Interpreting tissue concentrations, 2 ed. CRC Press, Boca Raton, pp. 603-618.

Skov, H., Heinänen, S., Zydelis, R., Bellebaum, J., Bzoma, S., Dagys, M., Durinck, J., Garthe, S., Grishanov, G., Hario, M., Kleckbusch, J.J., Kube, J., Kuresoo, A., Larsson, K., Luigujoe, L., Meissner, W., Nehls, H.W., Nilsson, L., Petersen, I.K., Roos, M.M., Pihl, S.S., Sonntag, N., Stock, A., Stipniece, A., Wahl, J., 2011. Waterbird populations and pressures in the Baltic Sea, TemaNord, Copenhagen.

Sørmo, E.G., Ciesielski, T.M., Øverjordet, I.B., Lierhagen, S., Eggen, G.S., Berg, T., Jenssen, B.M., 2011. Selenium moderates mercury toxicity in free-ranging freshwater fish. Environ. Sci. Technol. 45, 6561-6566.

Tong, S., von Schirnding, Y.E., Prapamontol, T., 2000. Environmental lead exposure: a public health problem of global dimensions. Bull. W. H. O.. 78, 1068-1077.

Vallius, H., 1999. Anthropogenically derived heavy metals in recent sediments of the Gulf of Finland, Baltic Sea. Chemosphere 38, 945-962.

Vallius, H., 2009. Heavy metal distribution in the modern soft surface sediments off the Finnish coast of the Gulf of Finland. Baltica 22, 65-76.

Vallius, H., 2014. Heavy metal concentrations in sediment cores from the northern Baltic Sea: Declines over the last two decades. Mar. Pollut. Bull. 79, 359-364. 
Vallius, H., 2015a. Applying sediment quality guidelines on soft sediments of the Gulf of Finland, Baltic Sea. Mar. Pollut. Bull. 98, 314-319.

Vallius, H., 2015b. Quality of the surface sediments of the northern coast of the Gulf of Finland, Baltic Sea. Mar. Pollut. Bull. 99, 250-255.

Waltho, C., Coulson, J., 2015. The Common Eider. T \& AD Poyser, an imprint of Bloomsbury Publishing London, UK.

Wayland, M., Alisauskas, R.T., Kellett, D., Traylor, J., Swoboda, C., Neugebauer, E., Mehl, K., 2007. Year-to-year correlations in blood metal levels among individuals of two species of North American sea ducks. Environ. Pollut. 150, 329-337.

Wayland, M., Drake, K.L., Alisauskas, R.T., Kellett, D.K., Traylor, J., Swoboda, C., Mehl, K., 2008. Survival rates and blood metal concentrations in two species of free-ranging North American sea ducks. Environ. Toxicol. Chem. 27, 698704.

Wayland, M., Garcia-Fernandez, A.J., Neugebauer, E., Gilchrist, H.G., 2001. Concentrations of cadmium, mercury and selenium in blood, liver and kidney of common eider ducks from the Canadian arctic. Environ. Mon. Assess. 71, 255-267.

Wayland, M., Scheuhammer, A.M., 2011. Cadmium in birds, environmental contaminants in biota: interpreting tissue concentrations, 2 ed. CRC Press, New York.

Weyers, B., Glück, E., Stoeppler, M., 1988. Investigation of the significance of heavy metal contents of blackbird feathers. Sci. Total Environ. 77, 61-67.

Wilson, H.M., Flint, P.L., Powell, A.N., 2007. Coupling contaminants with demography: effects of lead and selenium in Pacific common eiders. Environ. Toxicol. Chem. 26, 1410-1417.

Wolfe, M.F., Schwarzbach, S., Sulaiman, R.A., 1998. Effects of mercury on wildlife: A comprehensive review. Environ. Toxicol. Chem. 17, 146-160. 